\title{
Physical Activity of Children and Adolescents during the COVID-19 Pandemic-A Scoping Review
}

\author{
Lea Rossi *, Nick Behme and Christoph Breuer (D)
}

Institute of Sport Economics and Sport Management, German Sport University Cologne, 50933 Cologne, Germany; n.behme@dshs-koeln.de (N.B.); breuer@dshs-koeln.de (C.B.)

* Correspondence: 1.rossi@dshs-koeln.de

Citation: Rossi, L.; Behme, N.; Breuer, C. Physical Activity of Children and Adolescents during the COVID-19 Pandemic-A Scoping Review. Int. J. Environ. Res. Public Health 2021, 18, 11440. https:// doi.org/10.3390/ijerph182111440

Academic Editor: Paul B. Tchounwou

Received: 8 October 2021

Accepted: 29 October 2021

Published: 30 October 202

Publisher's Note: MDPI stays neutral with regard to jurisdictional claims in published maps and institutional affiliations.

Copyright: (c) 2021 by the authors. Licensee MDPI, Basel, Switzerland. This article is an open access article distributed under the terms and conditions of the Creative Commons Attribution (CC BY) license (https:/ / creativecommons.org/licenses/by/ $4.0 /)$.

\begin{abstract}
To counteract the COVIC-19 pandemic, many governments have introduced social distancing measures. While these restrictions helped contain the virus, it had adverse effects on individuals' mental and physical health-especially children. The aim of the present study is to review the evidence on the effects of COVID-19 restrictions on children's physical activity and their determinants. A scoping review was conducted in the databases PubMed, Web of Science, SportDiscus, and BISp-Surf. Inclusion criteria were empirical and peer-reviewed studies, youth samples, investigation of COVID19 restrictions, and investigating changes and/or determinants of physical activity before and during the COVID-19 pandemic. Risk of bias was assessed using the checklist by Downs and Black. The search resulted in 1672 studies, of which 84 studies were included in the analysis. The results highlighted a decrease in physical activity during the pandemic, ranging between $-10.8 \mathrm{~min} /$ day and $-91 \mathrm{~min} /$ day. If an increase was detected, it related to unstructured and outdoor activities. The main determinants of children's physical activity during the pandemic were age, gender, socioeconomic background, and the outdoor environment. The results imply that governments need to consider the negative effects that restrictive measures have on children's physical activity and act to ensure high levels of physical activity.
\end{abstract}

Keywords: exercise; sports; lockdown; public health

\section{Introduction}

Since December 2019, the SARS-CoV-2 virus, responsible for the COVID-19 disease, has spread across the globe and caused a global pandemic. The World Health Organization (WHO) declared it a public health emergency of international concern on 30 January 2020 [1]. Many national governments have introduced countermeasures to counteract the disease and avoid infections, including social distancing policies, closure of schools, shops and leisure opportunities, contact restrictions, and curfews. While these restrictions effectively slowed down the spread of the virus and contained the disease, they came with negative externalities as individuals were forced to stay home, which increased the risk of social isolation [2]. Restricting leisure opportunities such as sports also created a barrier to physical activity, while at the same time, sedentary time increased during lockdown due to more time spent at home [3]. In contrast, physical activity was widely recommended by national governments during the time to maintain a healthy lifestyle [4].

One population group that has been struck especially hard by the restrictive measures is children and adolescents. While young people are less likely to experience severe symptoms after infection [5], they were still confined through school closures and the close-down of leisure activities. This confinement could have adverse effects on children's physical and mental health as they did not get to play with their friends, be active in their sports groups, or have regular exercise in school physical education (PE) classes. This is especially dramatic as previous studies have shown that most children and adolescents did not reach the physical activity guidelines of 60 min of PA per day recommended by 
the $\mathrm{WHO}$ even before the pandemic [6]. A further reduction of physical activity during the pandemic could have harmful effects as PA during youth is an essential determinant for future PA [7], is an antecedent for mental health [8], and helps avoid future health challenges such as obesity and cardiovascular diseases [9].

While there have been several reviews on the effects of the COVID-19-pandemic on physical activity behaviors $[3,4,10,11]$, there is a lack of systematic evidence on the effects on children and adolescents specifically. This is especially important as children below the age of 12 are at this point unable to receive a vaccination against the virus and might face further restrictions in later waves of the virus. Thus, this study aims to (1) identify how far the restrictions have impacted the physical activity levels of children and adolescents and (2) identify which factors determine the physical activity levels. The latter enables us to derive practical implications for effective strategies to raise physical activity levels in future pandemic waves, respectively, in potential future pandemics. The research questions guiding our study are thus two-fold:

RQ1. How do the restrictions during the COVID-19 pandemic affect the physical activity behavior of children and adolescents?

RQ2. Which individual and context-specific factors determine the physical activity behavior of children and adolescents during the COVID-19 pandemic?

To address the research questions, a scoping review of existing studies on physical activity behaviors before and during the COVID-19 pandemic was conducted. In the following, information on the methods and main results are presented. The study concludes with practical implications based on the identified effects.

\section{Materials and Methods}

A scoping literature review was conducted on the changes in physical activity levels of children and adolescents during the COVID-19 pandemic. The approach of a scoping review was chosen as the body of evidence on physical activity and COVID-19 is rapidly growing and is rather heterogenous, which is problematic for a precise systematic review. The databases searched included PubMed, Web of Science, SportDiscus, and BISp-Surf. The last date of search was 1 July 2021. The search strategy was structured with the following search terms: sport and/or physical activity, children and/or adolescents and/or youth, COVID-19 and/or Corona. Searches were conducted both in English and in German to cover a broader range of research contexts.

Studies were included when the sample contained children and adolescents (under 18 years). This included both studies that focused exclusively on children and adolescents and population studies that included children and adolescents as a subgroup in their sample. Further, studies were included when COVID-19 restrictions were investigated. Thus, only studies published after March 2020 (when lockdown measures started in most countries) were considered in the present analysis. Another inclusion criterion was the investigation of changes and/or determinants of physical activity before and during the COVID-19 pandemic. This excluded studies that investigated physical activity as a determinant for mental or physical health outcomes. This inclusion criterion chosen as the focus was specifically on physical activity as an outcome rather than as a treatment for other outcomes. Lastly, studies were included when empirical data were presented and studies were peer-reviewed. Studies were collected by one author, and two authors independently reviewed the studies for inclusion/exclusion. In case of disagreement, a final decision on inclusion/exclusion was discussed until consensus was reached.

Studies included in the qualitative synthesis were summarized by two authors in an Excel spreadsheet and information on study characteristics and main interest results were gathered. Information was summarized on the country of interest (research context), research paradigm, study design, sample size and age of interest (of children), methods used, change of physical activity behavior, and determinants of physical activity behavior. These characteristics were considered when interpreting the results of studies. 
The principal summary measure was the change of physical activity behavior, which was coded "decrease" when studies reported a reduction of frequency or duration of physical activity, "increase" when studies reported growth of frequency or duration of physical activity behavior, and "no difference" when no significant differences were detected. Determinants of physical activity during the COVID-19 pandemic were gathered when significant effects were reported. Due to the high heterogeneity in the outcome measures (i.e., how physical activity was assessed), no meta-analysis could be performed and the studies were synthesized in a narrative review. Evidence was assessed to be certain when studies had low levels of risk and the majority of studies reported similar results.

Studies were assessed on their risk of bias using the checklist by Downs and Black [12]. The checklist was slightly adapted in item 27 , following previous review studies [13]. Two researchers assessed each study independently, and scores were compared in the aftermath. In case of divergence, the consensus was reached through in-depth assessment by both researchers jointly. Quality levels of studies were classified as excellent (scores 26-28), good (20-25), fair (15-19), and poor ( $\leq 14)$ following previous applications of the Downs and Black checklist [14].

\section{Results}

\subsection{Study Selection}

The search and identification process is illustrated in Figure 1.

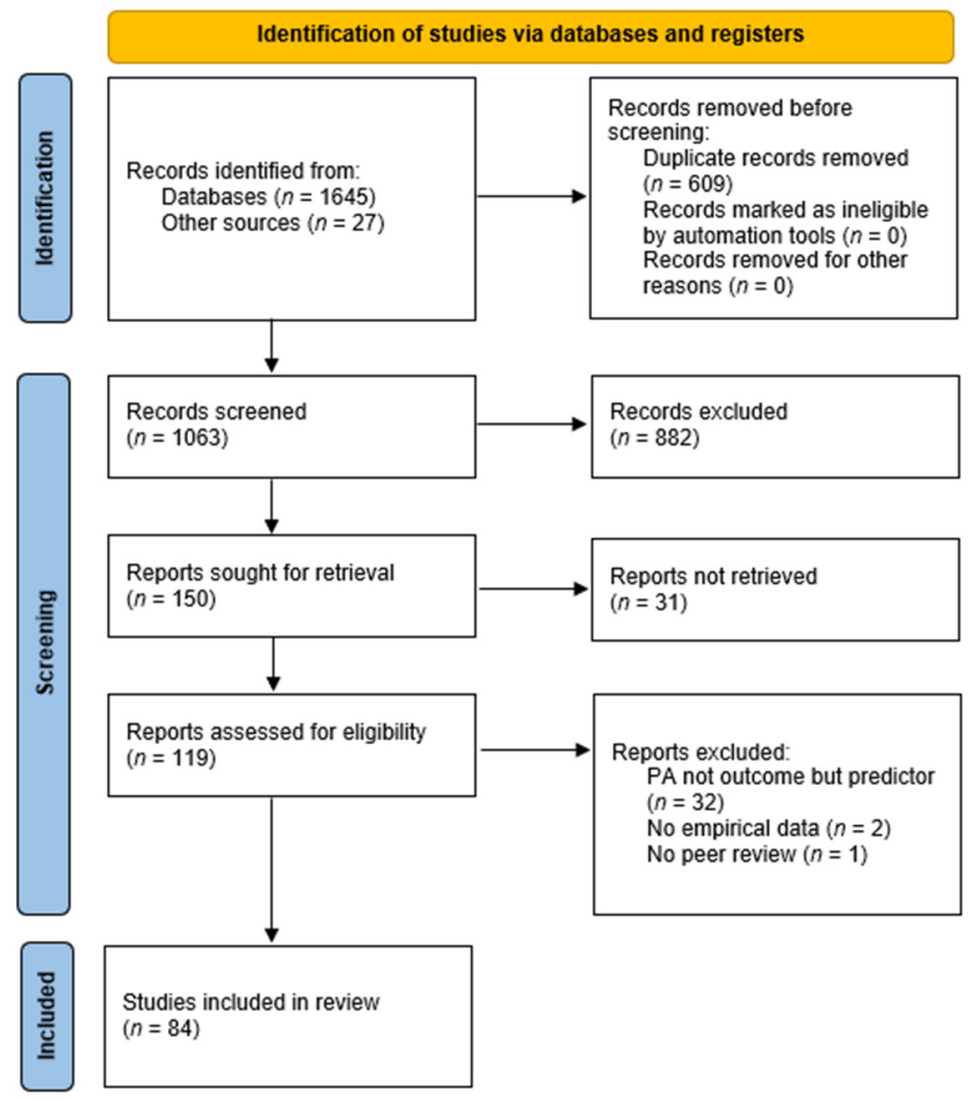

Figure 1. PRISMA flow chart of the study selection process.

The database search resulted in 1645 identified studies, enriched by 27 studies identified through additional searches in reference lists. After duplicates were removed, 1063 records remained, which were initially screened on eligibility based on their title and abstract. A total of 882 records were excluded as the study content and the topic of the study were considered irrelevant to the present analysis. The remaining 150 studies were sought for retrieval, of which 31 studies could not be retrieved. The remaining 119 studies 
were assessed on eligibility based on the full-text article, and 35 studies were excluded as they did not fulfil the inclusion criteria. Finally, 84 studies were included in the final synthesis of findings. An overview of the studies included in the analysis is presented in Appendix A.

\subsection{Study Characteristics}

The majority of studies included in the analysis stemmed from Western countries, including 25 studies from the Americas (North and South America), 33 studies from Europe, and 7 studies from Oceania. In contrast, 11 studies were conducted in Asia and only 2 studies stemmed from African countries. Five studies were classified as cross-continental as they included data from countries from different continents (see Table A1).

The research paradigm of the studies included in the analysis was predominantly quantitative, with 74 studies following a quantitative approach. Nine studies followed a qualitative paradigm and two studies used mixed-methods research. The majority of studies used a cross-sectional study design (59 studies), while 25 studies used a longitudinal design. One study employed a retrospective case-control design. The sample size of the studies included in the analyses ranged between $n=9$ and $n=16,177$. The total sample size cannot be stated as some studies used the same sample for their analysis. Many studies focused exclusively on children and adolescents, meaning that children and adolescents were questioned directly, or parents / caregivers were asked about children's behavior. A total of 22 studies focused on children up to 12 years, 21 studies focused on adolescents (12-19 years), and 30 studies investigated a sample including children and adolescents (119 years). In the final analysis, nine studies were general population studies that included children and adolescents as subgroups. The methods used by the studies in the final analysis mainly were surveys, particularly online surveys (66 studies). Three studies conducted phone interviews, five studies used semi-structured interviews, four studies used fitness or motor competence assessments, and two studies each used accelerometery, that is, step counts. Single studies made use of a cardiopulmonary stress test, a focus group, a case study (including observations and participant journals), community mobility data via Google, and an expert panel.

The assessment of risk of bias resulted in 50 studies rated as 'fair', 31 studies rated as 'poor', and three studies rated as 'good'. The rather low scores overall could be traced back to a lack of randomization and blinding in all studies as none of the studies were randomized-controlled trials due to the ad hoc nature of the research and the overall effect that the pandemic had on all study participants. Moreover, common concerns which occurred were the lack of a representative sample, neglection of confounders, and lack of an a priori power analysis.

\subsection{Change of Physical Activity Behavior}

On the primary variable of interest, most studies (57 studies) reported a decrease in physical activity, both in duration and frequency of physical activity (see Table 1). Four studies identified an increase in physical activity [15-18], whereas six studies could detect no significant difference in physical activity behaviors before and during the pandemic [19-24]. Eight studies reported differentiated results with indoor and organized sports and physical activity decreasing, while non-organized and outdoor sports and physical activity increased [25-32].

The decrease in time spent on physical activity ranged between $-45 \mathrm{~min} /$ day in Chile [33] to -91 $\mathrm{min} /$ day in Spain [34]. However, the measurement of physical activity differed substantially across the studies, which made the reporting of exact effects difficult. Thus, this range covers only those studies reporting concrete figures. The increase in physical activity was reported to be $+53 \mathrm{~min} /$ day in Sweden [17]. 
Table 1. Changes in physical activity (PA) of children and adolescents during the COVID-19 pandemic.

\begin{tabular}{cccc}
\hline Change of PA Identified & Min & Max & No. of Studies \\
\hline Decrease & $-45 \mathrm{~min} /$ day [33] & $-91 \mathrm{~min} /$ day [34] & 57 \\
\hline Increase & - & $+53 \mathrm{~min} /$ day [17] & 4 \\
\hline No change & - & - & 6 \\
\hline Mixed results & - & - & 8 \\
\hline
\end{tabular}

\subsection{Determinants of Physical Activity Behavior}

Thirty-four studies identified one or more determinants of the physical activity behavior of children and adolescents during the COVID-19 pandemic. Facilitating factors, meaning factors that enabled children and adolescents to be more physically active, were found on an individual level but also on a context level. Individual factors increasing physical activity of children were being male [35-37], following a daily routine [27,38], spending time on outdoor physical activity [35,38], taking part in online PE classes [27,38,39], more time available [40], no school [40], use of digital platforms [41], prior fitness status [28,42-44], and health-related quality of life [44]. Context-specific factors, i.e., factors relating to the family context, were having more than one child at home $[29,33,45]$, higher parental education [36], perceived parental capability [35], living in a house [46], low dwelling density [46], access to parks [46], parental encouragement and support [27,47,48], parental engagement in physical activity [47], family dog ownership [47], household income [47,48], family coexistence [49], and access and size of outdoor space available [45,48,50,51] (see Table 2).

Table 2. Facilitating factors in children's physical activity (PA) during the COVID-19 pandemic.

\begin{tabular}{|c|c|c|}
\hline Level & Facilitating Factor & No. of Studies \\
\hline \multirow{9}{*}{ Individual level } & Prior fitness status & 4 \\
\hline & Male gender & 3 \\
\hline & Taking part in online PE classes & 3 \\
\hline & Following a daily routine & 2 \\
\hline & Spending time on outdoor PA & 2 \\
\hline & More time available & 1 \\
\hline & No school & 1 \\
\hline & Use of digital platforms & 1 \\
\hline & Health-related quality of life & 1 \\
\hline \multirow{12}{*}{ Context level } & Size of outdoor space available & 4 \\
\hline & More than one child & 3 \\
\hline & Parental encouragement and support & 3 \\
\hline & Household income & 2 \\
\hline & Higher parental education & 1 \\
\hline & Perceived parental capability & 1 \\
\hline & Living in a house & 1 \\
\hline & Low dwelling density & 1 \\
\hline & Access to parks & 1 \\
\hline & Parental engagement in PA & 1 \\
\hline & Family dog ownership & 1 \\
\hline & Family coexistence & 1 \\
\hline
\end{tabular}


In contrast, studies also identified constraining factors, meaning factors that hindered children and adolescents from being physically active. These constraining factors were also individual or context-specific. Individual constraining factors included the child's age $[20,37,45,50,52,53]$, feelings of stress [54,55], feeling comfortable at home [55], having a migration background [34], lower socioeconomic status (SES) [29], change to routines [27], pre-COVID sedentary time [44], pre-COVID activity levels [51], and mood states [56]. Context-related constraints included the caregiver's level of education [32-34], living in an apartment [33], parent's age [47], parent's marital status [20], lack of playmates [57], family conflict [36,58], no outdoor space available [55], level of parents' stress [49], lack of supervision [57], proximity to major roads [46], restrictions from COVID-19 [40,48], club training cancellation [40], enrolment in an early education center [33], and urban environment [51,59] (see Table 3).

Table 3. Constraining factors in children's physical activity (PA) during the COVID-19 pandemic.

\begin{tabular}{|c|c|c|}
\hline Level & Constraining Factor & No. of Studies \\
\hline \multirow{9}{*}{ Individual level } & Child's age & 6 \\
\hline & Feelings of stress & 2 \\
\hline & Feeling comfortable at home & 1 \\
\hline & Having a migration background & 1 \\
\hline & Lower socioeconomic status & 1 \\
\hline & Change to routines & 1 \\
\hline & Pre-COVID sedentary time & 1 \\
\hline & Pre-COVID activity levels & 1 \\
\hline & Mood states & 1 \\
\hline \multirow{14}{*}{ Context level } & Caregiver's level of education & 3 \\
\hline & Family conflict & 2 \\
\hline & Restrictions from COVID-19 & 2 \\
\hline & Urban environment & 2 \\
\hline & Living in an apartment & 1 \\
\hline & Parent's age & 1 \\
\hline & Parent's marital status & 1 \\
\hline & Lack of playmates & 1 \\
\hline & No outdoor space available & 1 \\
\hline & Level of parent's stress & 1 \\
\hline & Lack of supervision & 1 \\
\hline & Proximity to major roads & 1 \\
\hline & Club training cancellation & 1 \\
\hline & Enrolment in an early education center & 1 \\
\hline
\end{tabular}

\section{Discussion}

When it comes to physical activity, behaviors of children and adolescents during the COVID-19 pandemic, the level of evidence is relatively strong, with a surprisingly high number of longitudinal studies. However, the review revealed a lack of methodological variety as most studies used online surveys. Moreover, there is a clear focus on Western countries (Australia, Canada, USA, Europe) with a lack of research into Asian and African countries. More research is needed in these regions (with the exception of China) to see how children and adolescents were affected by lockdown measures there. 
There is clear evidence for decreased physical activity during the lockdown in the studies identified in this review, especially in organized sports, as structured sports programs and facilities were closed. This shows that public recommendations for maintaining physical activity have so far been ineffective. If an increase has been detected, it occurred in outdoor play and unstructured activities $[15,26,29-31]$ or related to lower levels of national restrictions [17]. The increase in outdoor activities depends strongly on the housing environment. Thus, the pandemic and the resulting restrictions have further increased social differences between families with safe and spacious outdoor spaces and families living in dense environments.

This is also reflected in the determinants of children's physical activity behavior. The determinants identified by the studies mainly related to the parental and family background, the outdoor environment, participation in structured programs, including having a routine, and previous physical activity experiences. The role of parental education differed depending on the context. In European studies, higher education of parents increased physical activity, whereas in studies in Latin America, higher parental, especially maternal education harmed children's physical activity. This difference could hint at cultural differences or issues in time availability and strengthens our call for more research in different national contexts (especially Africa and Asia).

One predictor of children's physical activity identified in the review was the socioeconomic background. This complements general physical activity findings that children and adolescents with a higher SES are generally more physically active [60]. Once again, this difference relates to the built environment that children and adolescents are situated in as they provide little to no opportunities for physical activity-especially in times of a pandemic where indoor activities and crowded areas were restricted.

Last but not least, the problem of inactivity is especially prominent in females and older children and adolescents. This is especially concerning as the teenagers' age group had already shown decreasing activity levels before the pandemic [60]. Thus, the restrictions and lockdowns have intensified the problem even further. One reason for the steeper decline during the pandemic could be the more substantial reliance on routines and the lack of replacement programs for organized activities. A higher priority needs to be put on adolescents' routines to maintain a healthy and active lifestyle also during a pandemic.

The findings of the review lead to clear implications for policymakers. First, policymakers and educators need to educate and engage parents and caregivers in physical activity to increase physical activity levels overall ensuring consistent movement at baseline. One approach would be to include physical literacy into pre-school and school education agendas and make physical activity as one component of a healthy lifestyle a top priority in children's education.

Second, to create physical activity routines and thus maintain physical activity levels during phases of lockdowns, policymakers need to make online PE classes mandatory if schools need to close down again. Programs on digital platforms have been found to have a positive effect as well but to sustain participation and ensure that routines are kept, making these programs mandatory is critical.

Third, policymakers and city planners need to ensure a safe and movement-friendly outdoor environment with access to parks and playgrounds and low-density architecture. This is needed, especially in socially deprived areas, to decrease the divide between families with higher and lower SES. This divide has been illustrated once more during the pandemic - both in infection rates and physical activity behaviors.

Some limitations might constrain the explanatory power of this review. First, it is hard to compare all studies identified in the database search as studies were conducted during different stages of the COVID-19 pandemic. The search period included studies conducted between March 2020 and April 2021. As infection rates and restrictions differed between countries and stages of the pandemic, these findings cannot be related to specific lockdown measures. However, we tried to take these differences into account by considering the national context in interpreting studies. Moreover, the variability in measurement of 
physical activity across the studies limits the comparability further and makes general statements on the impact of the pandemic difficult.

Future research is needed to establish ongoing monitoring of the physical activity of children and adolescents. Potential long-term effects of the COVID-19 restrictions need to be identified, and effective countermeasures need to be developed. This review has given the first insight into the effects on children's physical activity and what can be done to counteract the decreasing activity. However, more research is needed to assess this in the long term. Moreover, generalized tools to measure the physical activity of children and adolescents need to be established to ensure comparability of results across studies and national contexts, which again enables researchers to track global long-term changes in physical activity. Lastly, while this review has focused on the changes and determinants of physical activity, governmental restrictions and the resulting decrease in physical activity have potential further effects on children and adolescents, i.e., decreasing scholastic performance or mental health. Future reviews should focus on these outcomes of decreasing physical activity to create a more holistic picture of the effects of the COVID19 pandemic on children and adolescents.

\section{Conclusions}

This scoping review has shown strong evidence for a negative effect of COVID19 restrictions on children's physical activity behavior. Physical activity has decreased especially with higher age of children and with a lower socioeconomic background. Thus, the COVID-19 pandemic has worsened the trend of inactivity which was alarming even before the pandemic.

While the review has uncovered a strong growth of research on the topic of physical activity of children and adolescents and COVID-19 since the start of the pandemic, it has also highlighted a lack of consistent measurement of physical activity levels which hinders the comparison of results between studies. Developing consistent measurement standards of physical activity should be part of a future research agenda to ensure that long-term developments of physical activity behaviors can be tracked and compared across national and international studies.

Author Contributions: Conceptualization, L.R. and C.B.; methodology, L.R., N.B. and C.B.; validation, L.R. and N.B.; formal analysis, L.R.; data curation, N.B.; writing-original draft preparation, L.R.; writing-review and editing, L.R., N.B. and C.B.; visualization, L.R.; supervision, C.B. All authors have read and agreed to the published version of the manuscript.

Funding: This research received no external funding.

Conflicts of Interest: The authors declare no conflict of interest. 


\section{Appendix A}

Table A1. Overview of studies included in the systematic review by continent (in alphabetic order).

\begin{tabular}{|c|c|c|c|c|c|c|c|c|}
\hline No. & Author, Year (Ref) & Country & Research Paradigm & Study Design & $\begin{array}{c}\text { Sample } \\
\text { (Age Incl.) }\end{array}$ & Method & Change of PA & Risk of Bias \\
\hline \multicolumn{9}{|c|}{ Americas } \\
\hline 1 & Aguilar-Farias et al., 2020 [33] & Chile & QUAN & Cross-sectional & $\begin{array}{c}n=3157 \\
(1-5 \text { years })\end{array}$ & Online survey & Decrease & Fair \\
\hline 2 & Bazett-Jones et al., 2020 [61] & USA & QUAN & Cross-sectional & $\begin{array}{c}n=287 \\
\text { (9-19 years) }\end{array}$ & Online survey & Decrease & Fair \\
\hline 3 & Beck et al., 2021 [62] & USA & QUAN & Cross-sectional & $\begin{array}{c}n=145 \\
(4-12 \text { years })\end{array}$ & Survey & Decrease & Fair \\
\hline 4 & Dayton et al., 2020 [63] & USA & QUAN & $\begin{array}{l}\text { Retrospective } \\
\text { case-control }\end{array}$ & $n=20$ (mean: 15.2 years) & $\begin{array}{l}\text { Cardiopulmonary } \\
\text { stress testing }\end{array}$ & Decrease & Fair \\
\hline 5 & Gama de Matos et al., 2020 [64] & Brazil & QUAN & Cross-sectional & $\begin{array}{c}n=426 \\
\text { (children, adolescents, } \\
\text { adults, elders) }\end{array}$ & Online survey & Decrease & Fair \\
\hline 6 & Dos Santos Cardoso de Sá, 2020 [65] & Brazil & QUAN & Cross-sectional & $\begin{array}{c}n=816 \\
(<12 \text { years })\end{array}$ & Online survey & Decrease & Poor \\
\hline 7 & Dunton et al., 2020 [66] & USA & QUAN & Cross-sectional & $\begin{array}{c}n=211 \\
(5-13 \text { years })\end{array}$ & Online survey & Decrease & Fair \\
\hline 8 & Eyler et al., 2021 [67] & USA & QUAN & Cross-sectional & $\begin{array}{c}n=245 \\
(5-12 \text { years })\end{array}$ & Online survey & Decrease & Fair \\
\hline 9 & Garcia et al., 2020 [68] & USA & QUAN & Longitudinal & $\begin{array}{c}n=9 \\
\text { (14-19 years) }\end{array}$ & Online survey & Decrease & Fair \\
\hline 11 & Hemphill et al., 2020 [69] & Canada & QUAN & Longitudinal & $\begin{array}{c}n=109 \\
(9-16 \text { years })\end{array}$ & $\begin{array}{l}\text { Step count via } \\
\text { Fitbit-Tracker }\end{array}$ & Decrease & Fair \\
\hline 12 & Kracht et al., 2021 [58] & USA & QUAN & Cross-sectional & $\begin{array}{c}n=1836 \\
(3-6 \text { years })\end{array}$ & Online survey & Decrease & Fair \\
\hline 13 & Lafave et al., 2021 [15] & Canada & QUAL & Cross-sectional & $\begin{array}{c}n=17 \\
(2-5 \text { years })\end{array}$ & $\begin{array}{l}\text { Semi-structured } \\
\text { interviews }\end{array}$ & Increase & Poor \\
\hline 14 & Malta et al., 2021 [70] & Brazil & QUAN & Cross-sectional & $\begin{array}{c}n=6470 \\
(12-17 \text { years })\end{array}$ & Online survey & Decrease & Poor \\
\hline 15 & McCormack et al., 2020 [25] & Canada & QUAN & Cross-sectional & $\begin{array}{c}n=328 \\
\text { (school-aged) }\end{array}$ & Online survey & $\begin{array}{l}\text { PA at home: increase } \\
\text { PA outdoors: } \\
\text { decrease }\end{array}$ & Fair \\
\hline 16 & Mitra et al., 2020 [46] & Canada & QUAN & Cross-sectional & $\begin{array}{c}n=1472 \\
(5-17 \text { years })\end{array}$ & Online survey & Decrease & Fair \\
\hline 17 & Moore et al., 2020 [47] & Canada & QUAN & Cross-sectional & $\begin{array}{c}n=1472 \\
(5-17 \text { years })\end{array}$ & Online survey & Decrease & Fair \\
\hline
\end{tabular}


Table A1. Cont.

\begin{tabular}{|c|c|c|c|c|c|c|c|c|}
\hline No. & Author, Year (Ref) & Country & Research Paradigm & Study Design & $\begin{array}{c}\text { Sample } \\
\text { (Age Incl.) }\end{array}$ & Method & Change of PA & Risk of Bias \\
\hline 18 & Pavlovic et al., 2021 [71] & USA & QUAN & Cross-sectional & $\begin{array}{c}n=2440 \\
\text { (PE teachers, school and } \\
\text { district administrators, } \\
\text { nurses, others) }\end{array}$ & Online survey & Decrease & Poor \\
\hline 19 & Pelletier et al., 2021 [26] & Canada & QUAL & Cross-sectional & $\begin{array}{c}n=21 \\
(7-12 \text { years })\end{array}$ & $\begin{array}{l}\text { Semi-structured } \\
\text { interview }\end{array}$ & $\begin{array}{c}\text { Increase in } \\
\text { unstructured } \\
\text { activity; decrease in } \\
\text { structured activity }\end{array}$ & Poor \\
\hline 21 & Riazi et al., 2021 [16] & Canada & QUAL & Cross-sectional & & $\begin{array}{l}\text { Semi-structured } \\
\text { interviews }\end{array}$ & Decrease & Poor \\
\hline 22 & Shepherd et al., 2021 [27] & Canada & QUAL & Cross-sectional & $\begin{array}{c}n=20 \\
\text { (high-school } \\
\text { student-athletes) }\end{array}$ & $\begin{array}{l}\text { Semi-structured } \\
\text { interviews }\end{array}$ & Variations & Poor \\
\hline 23 & Siegle et al., 2020 [50] & Brazil & QUAN & Cross-sectional & $\begin{array}{c}n=816 \\
(<13 \text { years })\end{array}$ & Online survey & Decrease & Fair \\
\hline 24 & Tulchin-Francis et al., 2021 [52] & USA & QUAN & Cross-sectional & $\begin{array}{c}n=1310 \\
(3-18 \text { years })\end{array}$ & Online survey & Decrease & Fair \\
\hline 25 & Wahl-Alexander and Camic, 2021 [72] & USA & QUAN & Longitudinal & $n=264$ (mean: 9.6 years) & $\begin{array}{l}\text { In-person testing } \\
\text { (BMI, fitness } \\
\text { assessment) }\end{array}$ & Decrease & Poor \\
\hline \multicolumn{9}{|c|}{ Europe } \\
\hline 26 & Androutsos et al., 2021 [73] & Greece & QUAN & Cross-sectional & $\begin{array}{c}n=397 \\
(2-18 \text { years })\end{array}$ & Online survey & Decrease & Fair \\
\hline 27 & Bronikowska et al., 2021 [28] & Poland & QUAN & Longitudinal & $n=127$ (mean: 15.4 years) & Online survey & $\begin{array}{c}\text { Increase in } \\
\text { previously inactive, } \\
\text { decrease in } \\
\text { previously active }\end{array}$ & Fair \\
\hline 28 & Chambonniere et al., 2021 [51] & France & QUAN & Cross-sectional & $\begin{array}{c}n=6491 \\
(6-17 \text { years })\end{array}$ & Online survey & Decrease & Poor \\
\hline 29 & Chen et al., 2021 [74] & Sweden & QUAN & Longitudinal & $\begin{array}{c}n=1316 \text { (mean: } 13.6 \text { years } \\
\text { at baseline) }\end{array}$ & Online survey & Decrease & Poor \\
\hline 30 & Dauty et al., 2020 [75] & France & QUAN & Longitudinal & $\begin{array}{c}n=19 \\
\text { (13-15 years) }\end{array}$ & $\begin{array}{l}\text { Pre- and } \\
\text { post-confinement } \\
\text { Yo-Yo Test }\end{array}$ & Decrease & Fair \\
\hline 31 & Delisle Nyström et al., 2020 [17] & Sweden & QUAN & Longitudinal & $\begin{array}{c}n=100 \\
(3-5 \text { years })\end{array}$ & $\begin{array}{l}\text { Phone interview, } \\
\text { accelerometer }\end{array}$ & Increase & Good \\
\hline 32 & Di Renzo et al., 2020 [19] & Italy & QUAN & Cross-sectional & $\begin{array}{c}n=3533 \\
(\geq 12 \text { years })\end{array}$ & Online survey & No difference & Fair \\
\hline
\end{tabular}


Table A1. Cont.

\begin{tabular}{|c|c|c|c|c|c|c|c|c|}
\hline No. & Author, Year (Ref) & Country & Research Paradigm & Study Design & $\begin{array}{c}\text { Sample } \\
\text { (Age Incl.) }\end{array}$ & Method & Change of PA & Risk of Bias \\
\hline 33 & Dragun et al., 2020 [20] & Croatia & QUAN & Longitudinal & $\begin{array}{c}n=1326 \text { (adolescents } \\
\text { medical students) }\end{array}$ & $\begin{array}{l}\text { Pre-COVID: } \\
\text { in-person survey } \\
\text { During COVID: } \\
\text { online survey }\end{array}$ & No difference & Fair \\
\hline 34 & Fillon et al., 2021 [76] & France & QUAN & Longitudinal & $\mathrm{n} / \mathrm{a}$ & Expert panel & Decrease & Poor \\
\hline 35 & Francisco et al., 2020 [77] & $\begin{array}{l}\text { Italy, Spain, } \\
\text { Portugal }\end{array}$ & QUAN & Cross-sectional & $\begin{array}{c}n=1480 \\
(3-18 \text { years })\end{array}$ & Online survey & Decrease & Poor \\
\hline 36 & Gallucio et al., 2021 [21] & Italy & QUAN & Cross-sectional & $\begin{array}{c}n=91 \\
\text { (15-17 years) }\end{array}$ & Online survey & No difference & Fair \\
\hline 37 & Gilic et al., 2020 [36] & $\begin{array}{l}\text { Bosnia and } \\
\text { Herzegovina }\end{array}$ & QUAN & Longitudinal & $\begin{array}{c}n=688 \\
(15-18 \text { years })\end{array}$ & Online survey & Decrease & Fair \\
\hline 38 & Jurak et al., 2021 [78] & Slovenia & QUAN & Longitudinal & $\begin{array}{c}n=20,000 \\
(6-14 \text { years })\end{array}$ & $\begin{array}{l}\text { SLOfit barometer, } \\
\text { fitness } \\
\text { measurements }\end{array}$ & Decrease & Poor \\
\hline 39 & Kolota and Glabska, 2021 [22] & Poland & QUAN & Cross-sectional & $\begin{array}{c}n=1334 \\
(10-16 \text { years })\end{array}$ & Online survey & No difference & Fair \\
\hline 40 & Kovacs et al., 2021 [38] & $\begin{array}{l}10 \text { Euro-pean } \\
\text { countries }\end{array}$ & QUAN & Cross-sectional & $\begin{array}{c}n=8395 \\
(6-18 \text { years })\end{array}$ & Online survey & Decrease & Poor \\
\hline 41 & López-Bueno et al., 2020 [79] & Spain & QUAN & Cross-sectional & $\begin{array}{c}n=860 \\
(3-16 \text { years })\end{array}$ & Online survey & Decrease & Fair \\
\hline 43 & Ng et al., 2020 [40] & Ireland & QUAN & Cross-sectional & $\begin{array}{c}n=1214 \\
(12-18 \text { years })\end{array}$ & Online survey & Decrease & Fair \\
\hline 44 & O'Kane et al., 2021 [23] & Ireland & MIXED & Longitudinal & $\begin{array}{c}n=281 \\
(12-14 \text { years })\end{array}$ & $\begin{array}{c}\text { Survey, } \\
\text { semi-structured } \\
\text { interviews }\end{array}$ & No difference & Fair \\
\hline 45 & Orgilés et al., 2020 [49] & Italy, Spain & QUAN & Cross-sectional & $\begin{array}{c}n=1143 \\
(3-18 \text { years })\end{array}$ & Online survey & Decrease & Poor \\
\hline 46 & Pietrobelli et al., 2020 [80] & Italy & QUAN & Longitudinal & $\begin{array}{c}n=41 \\
\text { (6-18 years) }\end{array}$ & $\begin{array}{c}\text { Pre-COVID: } \\
\text { in-person interview } \\
\text { During COVID: } \\
\text { phone interview }\end{array}$ & Decrease & Fair \\
\hline 47 & Pombo et al., 2020 [45] & Portugal & QUAN & Cross-sectional & $\begin{array}{c}n=2159 \\
(<13 \text { years })\end{array}$ & Online survey & - & Fair \\
\hline 48 & Pombo et al., 2021 [81] & Portugal & QUAN & Longitudinal & $\begin{array}{c}n=114 \\
(6-9 \text { years })\end{array}$ & $\begin{array}{l}\text { Motor competence } \\
\text { assessment }\end{array}$ & Decrease & Good \\
\hline 49 & Pombo et al., 2021 [82] & Portugal & QUAN & Cross-sectional & $\begin{array}{c}n=2159 \\
(<13 \text { years })\end{array}$ & Online survey & Decrease & Fair \\
\hline 50 & Poulain et al., 2021 [29] & Germany & QUAN & Longitudinal & $\begin{array}{c}n=285 \\
(1-10 \text { years })\end{array}$ & Online survey & $\begin{array}{l}\text { Playing outdoors: } \\
\text { increase } \\
\text { Indoor sports: } \\
\text { decrease }\end{array}$ & Fair \\
\hline
\end{tabular}


Table A1. Cont.

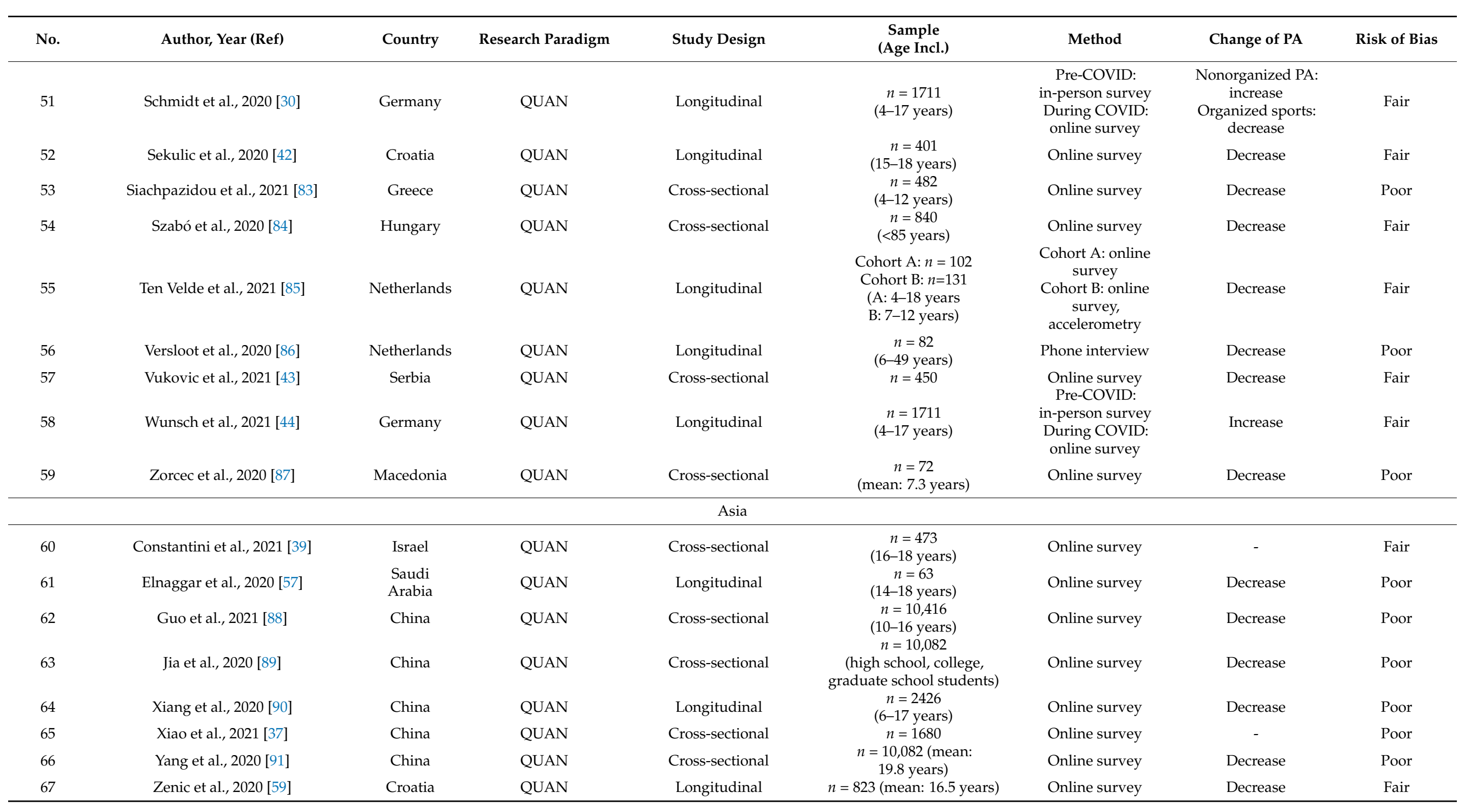


Table A1. Cont.

\begin{tabular}{|c|c|c|c|c|c|c|c|c|}
\hline No. & Author, Year (Ref) & Country & Research Paradigm & Study Design & $\begin{array}{c}\text { Sample } \\
\text { (Age Incl.) }\end{array}$ & Method & Change of PA & Risk of Bias \\
\hline 68 & Zhang et al., 2020 [56] & China & QUAN & Cross-sectional & $\begin{array}{c}n=9979 \\
(9-14 \text { years })\end{array}$ & Online survey & Decrease & Fair \\
\hline 69 & Zhou et al., 2021 [92] & China & QUAN & Cross-sectional & $\begin{array}{c}n=8115 \\
(15-33 \text { years })\end{array}$ & Online survey & Decrease & Fair \\
\hline 70 & Zhu et al., 2021 [18] & Hong Kong & QUAN & Cross-sectional & $\begin{array}{c}n=2863 \\
\text { (9-17 years) }\end{array}$ & In-person survey & Increase & Fair \\
\hline \multicolumn{9}{|c|}{ Africa } \\
\hline 71 & Abid et al., 2021 [93] & Tunisia & QUAN & Cross-sectional & $\begin{array}{c}n=100 \\
(5-12 \text { years })\end{array}$ & Online survey & Decrease & Fair \\
\hline 72 & Dixon et al., 2020 [53] & Kenya & QUAL & Cross-sectional & $\begin{array}{c}n=16 \\
(14-18 \text { years })\end{array}$ & $\begin{array}{c}\text { Case study } \\
\text { (observations, } \\
\text { participant journals) }\end{array}$ & Decrease & Poor \\
\hline \multicolumn{9}{|c|}{ Oceania } \\
\hline 73 & Elliott et al., 2021 [94] & Australia & QUAL & Cross-sectional & $\begin{array}{c}n=18 \\
(15-17 \text { years })\end{array}$ & $\begin{array}{l}\text { Online interviews, } \\
\text { focus groups }\end{array}$ & Decrease & Poor \\
\hline 74 & Masi et al., 2020 [95] & Australia & QUAN & Cross-sectional & $\begin{array}{c}n=302 \\
(2-17 \text { years })\end{array}$ & Online survey & Decrease & Poor \\
\hline 75 & Munasinghe et al., 2020 [96] & Australia & QUAN & Longitudinal & $\begin{array}{c}n=582 \\
(13-19 \text { years })\end{array}$ & $\begin{array}{l}\text { App survey, EMA, } \\
\text { smartphone sensors }\end{array}$ & Decrease & Fair \\
\hline 76 & Nathan et al., 2021 [31] & Australia & QUAN & Longitudinal & $\begin{array}{c}n=157 \\
\text { (5-9 years) }\end{array}$ & Online survey & $\begin{array}{c}\text { Unorganized PA: } \\
\text { increase } \\
\text { Organized PA: } \\
\text { decrease }\end{array}$ & Fair \\
\hline 77 & Parker et al., 2021 [41] & Australia & QUAN & Cross-sectional & $\begin{array}{c}n=963 \\
(13-17 \text { years })\end{array}$ & Online survey & - & Fair \\
\hline 78 & Reece et al., 2020 [97] & Australia & QUAN & Cross-sectional & $\begin{array}{c}n=16,177 \\
(4-18 \text { years) }\end{array}$ & Online survey & Decrease & Poor \\
\hline 79 & Sciberras et al., 2020 [54] & Australia & QUAN & Longitudinal & $\begin{array}{c}n=213 \\
(5-17 \text { years })\end{array}$ & Online survey & Decrease & Fair \\
\hline \multicolumn{9}{|c|}{ Cross-continental } \\
\hline 80 & Guan et al., 2020 [98] & 15 countries & QUAN & Cross-sectional & $\mathrm{n} / \mathrm{a}$ & $\begin{array}{c}\text { Community mobility } \\
\text { data (Google) }\end{array}$ & Decrease & Poor \\
\hline 81 & López-Aymes et al., 2021 [55] & $\begin{array}{l}\text { Spain, Latin } \\
\text { America }\end{array}$ & MIXED & Cross-sectional & $\begin{array}{c}n=234 \\
(\geq 18 \text { years })\end{array}$ & $\begin{array}{l}\text { Online survey, } \\
\text { discourse analysis }\end{array}$ & - & Poor \\
\hline 82 & López-Gil et al., 2021 [99] & Brazil, Spain & QUAN & Cross-sectional & $\begin{array}{c}n=1099 \\
(3-17 \text { years })\end{array}$ & Online survey & Decrease & Fair \\
\hline 83 & Okely et al., 2021 [24] & 14 countries & QUAN & Longitudinal & $\begin{array}{c}n=948 \\
(3-5 \text { years })\end{array}$ & Survey & No difference & Fair \\
\hline 84 & Ruíz-Roso et al., 2020 [32] & $\begin{array}{c}\text { Brazil, Chile, } \\
\text { Colombia, Spain, } \\
\text { Italy }\end{array}$ & QUAN & Cross-sectional & $\begin{array}{c}n=726 \\
(10-19 \text { years })\end{array}$ & Online survey & $\begin{array}{l}\text { Decrease overall } \\
\text { (increase in Italy, } \\
\text { Spain, Colombia) }\end{array}$ & Fair \\
\hline
\end{tabular}




\section{References}

1. World Health Organization (WHO). WHO Interactive Timeline: WHO's COVID-19 Response. Available online: https://www. who.int/emergencies/diseases/novel-coronavirus-2019/interactive-timeline (accessed on 22 July 2021).

2. Hwang, T.-J.; Rabheru, K.; Peisah, C.; Reichman, W.; Ikeda, M. Loneliness and social isolation during the COVID-19 pandemic. Int. Psychogeriatr. 2020, 32, 1217-1220. [CrossRef]

3. Stockwell, S.; Trott, M.; Tully, M.; Shin, J.; Barnett, Y.; Butler, L.; McDermott, D.; Schuch, F.; Smith, L. Changes in physical activity and sedentary behaviours from before to during the COVID-19 pandemic lockdown: A systematic review. BMJ Open Sport Exerc. Med. 2021, 7, e000960. [CrossRef] [PubMed]

4. Polero, P.; Rebollo-Seco, C.; Adsuar, J.C.; Pérez-Gómez, J.; Rojo-Ramos, J.; Manzano-Redondo, F.; Garcia-Gordillo, M.; CarlosVivas, J. Physical Activity Recommendations during COVID-19: Narrative Review. Int. J. Environ. Res. Public Health 2020, 18, 65. [CrossRef]

5. Kang, S.-J.; Jung, S.I. Age-Related Morbidity and Mortality among Patients with COVID-19. Infect. Chemother. 2020, 52, 154-164. [CrossRef]

6. Konstabel, K.; Verbestel, V.; Veidebaum, T.; Moreno, L.A.; Bammann, K.; Tornaritis, M.; Eiben, G.; Molnár, D.; Siani, A.; Sprengeler, O.; et al. Objectively measured physical activity in European children: The IDEFICS study. Int. J. Obes. 2014, 38, S135-S143. [CrossRef]

7. Scheerder, J.; Thomis, M.; Vanreusel, B.; Lefevre, J.; Renson, R.; Eynde, B.V.; Beunen, G.P. Sports Participation Among Females from Adolescence to Adulthood. Int. Rev. Sociol. Sport 2006, 41, 413-430. [CrossRef]

8. Rodriguez-Ayllon, M.; Cadenas-Sánchez, C.; Estévez-López, F.; Muñoz, N.E.; Mora-Gonzalez, J.; Migueles, J.H.; Molina-Garcia, P.; Henriksson, H.; Mena-Molina, A.; Martínez-Vizcaíno, V.; et al. Role of Physical Activity and Sedentary Behavior in the Mental Health of Preschoolers, Children and Adolescents: A Systematic Review and Meta-Analysis. Sports Med. 2019, 49, 1383-1410. [CrossRef]

9. García-Hermoso, A.; Ramírez-Campillo, R.; Izquierdo, M. Is Muscular Fitness Associated with Future Health Benefits in Children and Adolescents? A Systematic Review and Meta-Analysis of Longitudinal Studies. Sports Med. 2019, 49, 1079-1094. [CrossRef] [PubMed]

10. López-Valenciano, A.; Suárez-Iglesias, D.; Sanchez-Lastra, M.A.; Ayán, C. Impact of COVID-19 Pandemic on University Students' Physical Activity Levels: An Early Systematic Review. Front. Psychol. 2021, 11, 624567. [CrossRef]

11. Violant-Holz, V.; Gallego-Jiménez, M.G.; González-González, C.S.; Muñoz-Violant, S.; Rodríguez, M.J.; Sansano-Nadal, O.; Guerra-Balic, M. Psychological Health and Physical Activity Levels during the COVID-19 Pandemic: A Systematic Review. Int. J. Environ. Res. Public Health 2020, 17, 9419. [CrossRef]

12. Downs, S.H.; Black, N. The feasibility of creating a checklist for the assessment of the methodological quality both of randomised and non-randomised studies of health care interventions. J. Epidemiol. Community Health 1998, 52, 377-384. [CrossRef] [PubMed]

13. Mani-Babu, S.; Morrissey, D.; Waugh, C.; Screen, H.; Barton, C. The Effectiveness of Extracorporeal Shock Wave Therapy in Lower Limb Tendinopathy. Am. J. Sports Med. 2014, 43, 752-761. [CrossRef] [PubMed]

14. Williams, C.Y.K.; Townson, A.T.; Kapur, M.; Ferreira, A.F.; Nunn, R.; Galante, J.; Phillips, V.; Gentry, S.; Usher-Smith, J.A. Interventions to reduce social isolation and loneliness during COVID-19 physical distancing measures: A rapid systematic review. PLoS ONE 2021, 16, e0247139. [CrossRef] [PubMed]

15. Lafave, L.; Webster, A.D.; McConnell, C. Impact of COVID-19 on Early Childhood Educator's Perspectives and Practices in Nutrition and Physical Activity: A Qualitative Study. J. Fam. Econ. Issues 2021, 49, 935-945. [CrossRef]

16. Riazi, N.; Wunderlich, K.; Gierc, M.; Brussoni, M.; Moore, S.; Tremblay, M.; Faulkner, G. "You Can't Go to the Park, You Can't Go Here, You Can't Go There": Exploring Parental Experiences of COVID-19 and Its Impact on Their Children's Movement Behaviours. Children 2021, 8, 219. [CrossRef]

17. Nyström, C.D.; Alexandrou, C.; Henström, M.; Nilsson, E.; Okely, A.; Wehbe El Masri, S.; Löf, M. International Study of Movement Behaviors in the Early Years (SUNRISE): Results from SUNRISE Sweden's Pilot and COVID-19 Study. Int. J. Environ. Res. Public Health 2020, 17, 8491. [CrossRef]

18. Zhu, S.; Zhuang, Y.; Ip, P. Impacts on Children and Adolescents' Lifestyle, Social Support and Their Association with Negative Impacts of the COVID-19 Pandemic. Int. J. Environ. Res. Public Health 2021, 18, 4780. [CrossRef]

19. Di Renzo, L.; Gualtieri, P.; Pivari, F.; Soldati, L.; Attinà, A.; Cinelli, G.; Leggeri, C.; Caparello, G.; Barrea, L.; Scerbo, F.; et al. Eating habits and lifestyle changes during COVID-19 lockdown: An Italian survey. J. Transl. Med. 2020, 18, 229. [CrossRef] [PubMed]

20. Dragun, R.; Veček, N.; Marendić, M.; Pribisalić, A.; Đivić, G.; Cena, H.; Polašek, O.; Kolčić, I. Have Lifestyle Habits and Psychological Well-Being Changed among Adolescents and Medical Students Due to COVID-19 Lockdown in Croatia? Nutrients 2020, 13, 97. [CrossRef]

21. Galluccio, A.; Caparello, G.; Avolio, E.; Manes, E.; Ferraro, S.; Giordano, C.; Sisci, D.; Bonofiglio, D. Self-Perceived Physical Activity and Adherence to the Mediterranean Diet in Healthy Adolescents during COVID-19: Findings from the DIMENU Pilot Study. Healthcare 2021, 9, 622. [CrossRef] 
22. Kołota, A.; Głąbska, D. COVID-19 Pandemic and Remote Education Contributes to Improved Nutritional Behaviors and Increased Screen Time in a Polish Population-Based Sample of Primary School Adolescents: Diet and Activity of Youth during COVID-19 (DAY-19) Study. Nutrients 2021, 13, 1596. [CrossRef]

23. O'Kane, S.M.; Lahart, I.M.; Gallagher, A.M.; Carlin, A.; Faulkner, M.; Jago, R.; Murphy, M.H. Changes in Physical Activity, Sleep, Mental Health, and Social Media Use During COVID-19 Lockdown Among Adolescent Girls: A Mixed-Methods Study. J. Phys. Act. Health 2021, 18, 677-685. [CrossRef] [PubMed]

24. Okely, A.D.; Kariippanon, K.E.; Guan, H.; Taylor, E.K.; Suesse, T.; Cross, P.L.; Chong, K.H.; Suherman, A.; Turab, A.; Staiano, A.E.; et al. Global effect of COVID-19 pandemic on physical activity, sedentary behaviour and sleep among 3 to 5-year-old children: A longitudinal study of 14 countries. BMC Public Health 2021, 21, 1-15. [CrossRef] [PubMed]

25. McCormack, G.R.; Doyle-Baker, P.K.; Petersen, J.A.; Ghoneim, D. Parent anxiety and perceptions of their child's physical activity and sedentary behaviour during the COVID-19 pandemic in Canada. Prev. Med. Rep. 2020, 20, 101275. [CrossRef]

26. Pelletier, C.; Cornish, K.; Sanders, C. Children's Independent Mobility and Physical Activity during the COVID-19 Pandemic: A Qualitative Study with Families. Int. J. Environ. Res. Public Health 2021, 18, 4481. [CrossRef]

27. Shepherd, H.; Evans, T.; Gupta, S.; McDonough, M.; Doyle-Baker, P.; Belton, K.; Karmali, S.; Pawer, S.; Hadly, G.; Pike, I.; et al. The Impact of COVID-19 on High School Student-Athlete Experiences with Physical Activity, Mental Health, and Social Connection. Int. J. Environ. Res. Public Health 2021, 18, 3515. [CrossRef]

28. Bronikowska, M.; Krzysztoszek, J.; Łopatka, M.; Ludwiczak, M.; Pluta, B. Comparison of Physical Activity Levels in Youths before and during a Pandemic Lockdown. Int. J. Environ. Res. Public Health 2021, 18, 5139. [CrossRef]

29. Poulain, T.; Meigen, C.; Sobek, C.; Ober, P.; Igel, U.; Körner, A.; Kiess, W.; Vogel, M. Loss of childcare and classroom teaching during the COVID-19-related lockdown in spring 2020: A longitudinal study on consequences on leisure behavior and schoolwork at home. PLoS ONE 2021, 16, e0247949. [CrossRef] [PubMed]

30. Schmidt, S.C.E.; Anedda, B.; Burchartz, A.; Eichsteller, A.; Kolb, S.; Nigg, C.; Niessner, C.; Oriwol, D.; Worth, A.; Woll, A. Physical activity and screen time of children and adolescents before and during the COVID-19 lockdown in Germany: A natural experiment. Sci. Rep. 2020, 10, 1-12. [CrossRef]

31. Nathan, A.; George, P.; Ng, M.; Wenden, E.; Bai, P.; Phiri, Z.; Christian, H. Impact of COVID-19 Restrictions on Western Australian Children's Physical Activity and Screen Time. Int. J. Environ. Res. Public Health 2021, 18, 2583. [CrossRef]

32. Ruíz-Roso, M.; Padilha, P.D.C.; Matilla-Escalante, D.; Brun, P.; Ulloa, N.; Acevedo-Correa, D.; Peres, W.A.F.; Martorell, M.; Carrilho, T.R.B.; Cardoso, L.D.O.; et al. Changes of Physical Activity and Ultra-Processed Food Consumption in Adolescents from Different Countries during COVID-19 Pandemic: An Observational Study. Nutrients 2020, 12, 2289. [CrossRef] [PubMed]

33. Aguilar-Farias, N.; Toledo-Vargas, M.; Miranda-Marquez, S.; Cortinez-O'Ryan, A.; Cristi-Montero, C.; Rodriguez-Rodriguez, F.; Martino-Fuentealba, P.; Okely, A.; Cruz, B.D.P. Sociodemographic Predictors of Changes in Physical Activity, Screen Time, and Sleep among Toddlers and Preschoolers in Chile during the COVID-19 Pandemic. Int. J. Environ. Res. Public Health 2020, $18,176$. [CrossRef]

34. Medrano, M.; Cadenas-Sanchez, C.; Oses, M.; Arenaza, L.; Amasene, M.; Labayen, I. Changes in lifestyle behaviours during the COVID-19 confinement in Spanish children: A longitudinal analysis from the MUGI project. Pediatric Obes. 2020, 16 , e12731. [CrossRef] [PubMed]

35. Guerrero, M.; Vanderloo, L.; Rhodes, R.; Faulkner, G.; Moore, S.; Tremblay, M. Canadian children's and youth's adherence to the 24-h movement guidelines during the COVID-19 pandemic: A decision tree analysis. J. Sport Health Sci. 2020, 9, $313-321$. [CrossRef] [PubMed]

36. Gilic, B.; Ostojic, L.; Corluka, M.; Volaric, T.; Sekulic, D. Contextualizing Parental/Familial Influence on Physical Activity in Adolescents before and during COVID-19 Pandemic: A Prospective Analysis. Children 2020, 7, 125. [CrossRef] [PubMed]

37. Xiao, S.; Yan, Z.; Zhao, L. Physical Activity, Screen Time, and Mood Disturbance Among Chinese Adolescents During COVID-19. J. Psychosoc. Nurs. Ment. Health Serv. 2021, 59, 14-20. [CrossRef]

38. Kovacs, V.A.; Starc, G.; Brandes, M.; Kaj, M.; Blagus, R.; Leskošek, B.; Suesse, T.; Dinya, E.; Guinhouya, B.C.; Zito, V.; et al. Physical activity, screen time and the COVID-19 school closures in Europe-An observational study in 10 countries. Eur. J. Sport Sci. 2021, 373, 1-10. [CrossRef]

39. Constantini, K.; Markus, I.; Epel, N.; Jakobovich, R.; Gepner, Y.; Lev-Ari, S. Continued Participation of Israeli Adolescents in Online Sports Programs during the COVID-19 Pandemic Is Associated with Higher Resilience. Int. J. Environ. Res. Public Health 2021, 18, 4386. [CrossRef]

40. Ng, K.; Cooper, J.; McHale, F.; Clifford, J.; Woods, C. Barriers and facilitators to changes in adolescent physical activity during COVID-19. BMJ Open Sport Exerc. Med. 2020, 6, e000919. [CrossRef]

41. Parker, K.; Uddin, R.; Ridgers, N.D.; Brown, H.; Veitch, J.; Salmon, J.; Timperio, A.; Sahlqvist, S.; Cassar, S.; Toffoletti, K.; et al. The Use of Digital Platforms for Adults' and Adolescents' Physical Activity During the COVID-19 Pandemic (Our Life at Home): Survey Study. J. Med. Internet Res. 2021, 23, e23389. [CrossRef]

42. Sekulic, D.; Blazevic, M.; Gilic, B.; Kvesic, I.; Zenic, N. Prospective Analysis of Levels and Correlates of Physical Activity during COVID-19 Pandemic and Imposed Rules of Social Distancing; Gender Specific Study among Adolescents from Southern Croatia. Sustainability 2020, 12, 4072. [CrossRef]

43. Vuković, J.; Matić, R.; Milovanović, I.; Maksimović, N.; Krivokapić, D.; Pišot, S. Children's Daily Routine Response to COVID19 Emergency Measures in Serbia. Front. Pediatr. 2021, 9, 154. [CrossRef] 
44. Wunsch, K.; Nigg, C.; Niessner, C.; Schmidt, S.; Oriwol, D.; Hanssen-Doose, A.; Burchartz, A.; Eichsteller, A.; Kolb, S.; Worth, A.; et al. The Impact of COVID-19 on the Interrelation of Physical Activity, Screen Time and Health-Related Quality of Life in Children and Adolescents in Germany: Results of the Motorik-Modul Study. Children 2021, 8, 98. [CrossRef] [PubMed]

45. Pombo, A.; Luz, C.; de Sá, C.; Rodrigues, L.; Cordovil, R. Effects of the COVID-19 Lockdown on Portuguese Children's Motor Competence. Children 2021, 8, 199. [CrossRef] [PubMed]

46. Mitra, R.; Moore, S.A.; Gillespie, M.; Faulkner, G.; Vanderloo, L.M.; Chulak-Bozzer, T.; Rhodes, R.E.; Brussoni, M.; Tremblay, M.S Healthy movement behaviours in children and youth during the COVID-19 pandemic: Exploring the role of the neighbourhood environment. Health Place 2020, 65, 102418. [CrossRef]

47. Moore, S.A.; Faulkner, G.; Rhodes, R.E.; Brussoni, M.; Chulak-Bozzer, T.; Ferguson, L.J.; Mitra, R.; O’Reilly, N.; Spence, J.C.; Vanderloo, L.M.; et al. Impact of the COVID-19 virus outbreak on movement and play behaviours of Canadian children and youth: A national survey. Int. J. Behav. Nutr. Phys. Act. 2020, 17, 1-11. [CrossRef]

48. Perez, D.; Thalken, J.; Ughelu, N.; Knight, C.; Massey, W. Nowhere to Go: Parents' Descriptions of Children's Physical Activity During a Global Pandemic. Front. Public Health 2021, 9, 642932. [CrossRef]

49. Orgilés, M.; Morales, A.; DelVecchio, E.; Mazzeschi, C.; Espada, J.P. Immediate Psychological Effects of the COVID-19 Quarantine in Youth from Italy and Spain. Front. Psychol. 2020, 11, 579038. [CrossRef]

50. Siegle, C.B.H.; Pombo, A.; Luz, C.; Rodrigues, L.P.; Cordovil, R.; Sá, C.D.S.C.D. Influences of family and household characteristics on children's level of physical activity during social distancing due to COVID-19 in brazil. Rev. Paul. de Pediatr. 2021, 39 , e2020297. [CrossRef]

51. Chambonniere, C.; Lambert, C.; Fearnbach, N.; Tardieu, M.; Fillon, A.; Genin, P.; Larras, B.; Melsens, P.; Bois, J.; Pereira, B.; et al. Effect of the COVID-19 lockdown on physical activity and sedentary behaviors in French children and adolescents: New results from the ONAPS national survey. Eur. J. Integr. Med. 2021, 43, 101308. [CrossRef]

52. Tulchin-Francis, K.; Stevens, W.; Gu, X.; Zhang, T.; Roberts, H.; Keller, J.; Dempsey, D.; Borchard, J.; Jeans, K.; VanPelt, J. The impact of the coronavirus disease 2019 pandemic on physical activity in U.S. children. J. Sport Health Sci. 2021, 10, 323-332. [CrossRef]

53. Dixon, M.A.; Hardie, A.; Warner, S.M.; Owiro, E.A.; Orek, D. Sport for Development and COVID-19: Responding to Change and Participant Needs. Front. Sports Act. Living 2020, 2, 590151. [CrossRef]

54. Sciberras, E.; Patel, P.; Stokes, M.A.; Coghill, D.; Middeldorp, C.M.; Bellgrove, M.A.; Becker, S.P.; Efron, D.; Stringaris, A.; Faraone, S.V.; et al. Physical Health, Media Use, and Mental Health in Children and Adolescents with ADHD During the COVID-19 Pandemic in Australia. J. Atten. Disord. 2020. [CrossRef]

55. López-Aymes, G.; Valadez, M.D.L.D.; Rodríguez-Naveiras, E.; Castellanos-Simons, D.; Aguirre, T.; Borges, A. A Mixed Methods Research Study of Parental Perception of Physical Activity and Quality of Life of Children Under Home Lock Down in the COVID-19 Pandemic. Front. Psychol. 2021, 12, 649481. [CrossRef]

56. Zhang, X.; Zhu, W.; Kang, S.; Qiu, L.; Lu, Z.; Sun, Y. Association between Physical Activity and Mood States of Children and Adolescents in Social Isolation during the COVID-19 Epidemic. Int. J. Environ. Res. Public Health 2020, 17, 7666. [CrossRef]

57. Elnaggar, R.K.; Alqahtani, B.A.; Mahmoud, W.S.; ElFakharany, M.S. Physical Activity in Adolescents During the Social Distancing Policies of the COVID-19 Pandemic. Asia Pac. J. Public Health 2020, 32, 491-494. [CrossRef] [PubMed]

58. Kracht, C.; Katzmarzyk, P.; Staiano, A. Household chaos, family routines, and young child movement behaviors in the US during the COVID-19 outbreak: A cross-sectional study. BMC Public Health 2021, 21, 860. [CrossRef] [PubMed]

59. Zenic, N.; Taiar, R.; Gilic, B.; Blazevic, M.; Maric, D.; Pojskic, H.; Sekulic, D. Levels and Changes of Physical Activity in Adolescents during the COVID-19 Pandemic: Contextualising Urban vs. Rural Living Environment. Appl. Sci. 2020, 10, 3997. [CrossRef]

60. Vandermeerschen, H.; Vos, S.; Scheerder, J. Towards level playing fields? A time trend analysis of young people's participation in club-organised sports. Int. Rev. Sociol. Sport 2014, 51, 468-484. [CrossRef]

61. Bazett-Jones, D.M.; Garcia, M.C.; Taylor-Haas, J.A.; Long, J.T.; Rauh, M.J.; Paterno, M.V.; Ford, K.R. Impact of COVID-19 Social Distancing Restrictions on Training Habits, Injury, and Care Seeking Behavior in Youth Long-Distance Runners. Front. Sports Act. Living 2020, 2, 586141. [CrossRef]

62. Beck, A.; Huang, J.; Lendzion, L.; Fernandez, A.; Martinez, S. Impact of the COVID-19 pandemic on parents' perception of health behaviors in children with overweight and obesity. Acad. Pediatr. 2021, in press. [CrossRef]

63. Dayton, J.D.; Ford, K.; Carroll, S.J.; Flynn, P.A.; Kourtidou, S.; Holzer, R.J. The Deconditioning Effect of the COVID-19 Pandemic on Unaffected Healthy Children. Pediatr. Cardiol. 2021, 42, 554-559. [CrossRef]

64. de Matos, D.G.; Aidar, F.J.; de Almeida-Neto, P.F.; Moreira, O.C.; de Souza, R.F.; Marçal, A.C.; Marcucci-Barbosa, L.S.; Júnior, F.d.M.; Lobo, L.F.; Santos, J.L.d.; et al. The Impact of Measures Recommended by the Government to Limit the Spread of Coronavirus (COVID-19) on Physical Activity Levels, Quality of Life, and Mental Health of Brazilians. Sustainability 2020, 12, 9072. [CrossRef]

65. Sá, C.D.S.C.D.; Pombo, A.; Luz, C.; Rodrigues, L.P.; Cordovil, R. COVID-19 Social Isolation in Brazil: Effects on the Physical Activity Routine of Families with Children. Rev. Paul. De Pediatr. 2021, 39, e2020159. [CrossRef] [PubMed]

66. Dunton, G.; Do, B.; Wang, S. Early effects of the COVID-19 pandemic on physical activity and sedentary behavior in children living in the US. BMC Public Health 2020, 20, 1351. [CrossRef]

67. Eyler, A.A.; Schmidt, L.; Kepper, M.; Mazzucca, S.; Gilbert, A.; Beck, A. Parent Perceptions of Changes in Child Physical Activity During COVID-19 Stay-At-Home Orders. Front. Public Health 2021, 9, 637151. [CrossRef] 
68. Garcia, J.M.; Lawrence, S.; Brazendale, K.; Leahy, N.; Fukuda, D. Brief report: The impact of the COVID-19 pandemic on health behaviors in adolescents with Autism Spectrum Disorder. Disabil. Health J. 2021, 14, 101021. [CrossRef]

69. Hemphill, N.M.; Kuan, M.T.; Harris, K.C. Reduced Physical Activity During COVID-19 Pandemic in Children with Congenital Heart Disease. Can. J. Cardiol. 2020, 36, 1130-1134. [CrossRef]

70. Malta, D.C.; Gomes, C.S.; Barros, M.B.D.A.; Lima, M.G.; da Silva, A.G.; Cardoso, L.S.D.M.; Werneck, A.O.; da Silva, D.R.P.; Ferreira, A.P.D.S.; Romero, D.E.; et al. The COVID-19 pandemic and changes in the lifestyles of Brazilian adolescents. Rev. Bras. Epidemiol. 2021, 24, e210012. [CrossRef]

71. Pavlovic, A.; DeFina, L.F.; Natale, B.L.; Thiele, S.E.; Walker, T.J.; Craig, D.W.; Vint, G.R.; Leonard, D.; Haskell, W.L.; Kohl, H.W. Keeping children healthy during and after COVID-19 pandemic: Meeting youth physical activity needs. BMC Public Health 2021, 21, 1-8. [CrossRef]

72. Wahl-Alexander, Z; Camic, C.L. Impact of COVID-19 on School-Aged Male and Female Health-Related Fitness Markers. Pediatr. Exerc. Sci. 2021, 33, 61-64. [CrossRef]

73. Androutsos, O.; Perperidi, M.; Georgiou, C.; Chouliaras, G. Lifestyle Changes and Determinants of Children's and Adolescents' Body Weight Increase during the First COVID-19 Lockdown in Greece: The COV-EAT Study. Nutrients 2021, 13, 930. [CrossRef]

74. Chen, Y.; Osika, W.; Henriksson, G.; Dahlstrand, J.; Friberg, P. Impact of COVID-19 pandemic on mental health and health behaviors in Swedish adolescents. Scand. J. Public Health 2021. [CrossRef]

75. Dauty, M.; Menu, P.; Fouasson-Chailloux, A. Effects of the COVID-19 confinement period on physical conditions in young elite soccer players. J. Sports Med. Phys. Fit. 2021, 61, 1252-1257. [CrossRef]

76. Fillon, A.; Genin, P.; Larras, B.; Vanhelst, J.; Luiggi, M.; Aubert, S.; Verdot, C.; Rey, O.; Lhuisset, L.; Bois, J.; et al. France's 2020 Report Card on Physical Activity and Sedentary Behaviors in Children and Youth: Results and Progression. J. Phys. Act. Health 2021, 18, 811-817. [CrossRef] [PubMed]

77. Francisco, R.; Pedro, M.; DelVecchio, E.; Espada, J.P.; Morales, A.; Mazzeschi, C.; Orgilés, M. Psychological Symptoms and Behavioral Changes in Children and Adolescents During the Early Phase of COVID-19 Quarantine in Three European Countries. Front. Psychiatry 2020, 11, 570164. [CrossRef] [PubMed]

78. Jurak, G.; Morrison, S.A.; Kovač, M.; Leskošek, B.; Sember, V.; Strel, J.; Starc, G. A COVID-19 Crisis in Child Physical Fitness: Creating a Barometric Tool of Public Health Engagement for the Republic of Slovenia. Front. Public Health 2021, 9, 644235. [CrossRef] [PubMed]

79. López-Bueno, R.; López-Sánchez, G.F.; Casajús, J.A.; Calatayud, J.; Gil-Salmerón, A.; Grabovac, I.; Tully, M.A.; Smith, L. HealthRelated Behaviors Among School-Aged Children and Adolescents During the Spanish COVID-19 Confinement. Front. Pediatr. 2020, 8, 573. [CrossRef]

80. Pietrobelli, A.; Pecoraro, L.; Ferruzzi, A.; Heo, M.; Faith, M.; Zoller, T.; Antoniazzi, F.; Piacentini, G.; Fearnbach, S.N.; Heymsfield, S.B. Effects of COVID-19 Lockdown on Lifestyle Behaviors in Children with Obesity Living in Verona, Italy: A Longitudinal Study. Obesity 2020, 28, 1382-1385. [CrossRef] [PubMed]

81. Pombo, A.; Luz, C.; Rodrigues, L.P.; Cordovil, R. Effects of COVID-19 Confinement on the Household Routines of Children in Portugal. J. Child Fam. Stud. 2021, 30, 1664-1674. [CrossRef]

82. Pombo, A.; Luz, C.; Rodrigues, L.; Ferreira, C.; Cordovil, R. Correlates of children's physical activity during the COVID19 confinement in Portugal. Public Health 2020, 189, 14-19. [CrossRef]

83. Siachpazidou, D.; Kotsiou, O.; Chatziparasidis, G.; Papagiannis, D.; Vavougios, G.; Gogou, E.; Stavrou, V.; Gourgoulianis, K. Action and Reaction of Pre-Primary and Primary School-Age Children to Restrictions during COVID-19 Pandemic in Greece. J. Pers. Med. 2021, 11, 451. [CrossRef]

84. Szabó, T.; Stocker, M.; Ács, P.; Morvay-Sey, K.; Pálvölgyi, A.; Laczkó, T. Impact of COVID-19 on the physical activity and well-being of hungarian athletes and sports professionals. Health Probl. Civiliz. 2020, 14, 165-173. [CrossRef]

85. ten Velde, G.; Lubrecht, J.; Arayess, L.; van Loo, C.; Hesselink, M.; Reijnders, D.; Vreugdenhil, A. Physical activity behaviour and screen time in Dutch children during the COVID-19 pandemic: Pre-, during- and post-school closures. Pediatr. Obes. 2021, 16, e12779. [CrossRef]

86. Versloot, O.; van der Net, J.; Fischer, K. Sports participation of patients with haemophilia in the COVID-19 era: The Dutch experience. Haemophilia 2020, 27, e295-e297. [CrossRef] [PubMed]

87. Zorcec, T.; Jakovska, T.; Micevska, V.; Boskovska, K.; Cholakovska, V.C. Pandemic with COVID-19 and Families with Children with Chronic Respiratory Diseases. PRILOZI 2020, 41, 95-101. [CrossRef]

88. Guo, Y.-F.; Liao, M.-Q.; Cai, W.-L.; Yu, X.-X.; Li, S.-N.; Ke, X.-Y.; Tan, S.-X.; Luo, Z.-Y.; Cui, Y.-F.; Wang, Q.; et al. Physical activity, screen exposure and sleep among students during the pandemic of COVID-19. Sci. Rep. 2021, 11, 1-11. [CrossRef]

89. Jia, P.; Zhang, L.; Yu, W.; Yu, B.; Liu, M.; Zhang, D.; Yang, S. Impact of COVID-19 lockdown on activity patterns and weight status among youths in China: The COVID-19 Impact on Lifestyle Change Survey (COINLICS). Int. J. Obes. 2020, 45, 695-699. [CrossRef]

90. Xiang, M.; Zhang, Z.; Kuwahara, K. Impact of COVID-19 pandemic on children and adolescents' lifestyle behavior larger than expected. Prog. Cardiovasc. Dis. 2020, 63, 531-532. [CrossRef]

91. Yang, S.; Guo, B.; Ao, L.; Yang, C.; Zhang, L.; Zhou, J.; Jia, P. Obesity and activity patterns before and during COVID-19 lockdown among youths in China. Clin. Obes. 2020, 10, e12416. [CrossRef] [PubMed] 
92. Zhou, J.; Xie, X.; Guo, B.; Pei, R.; Pei, X.; Yang, S.; Jia, P. Impact of COVID-19 Lockdown on Physical Activity Among the Chinese Youths: The COVID-19 Impact on Lifestyle Change Survey (COINLICS). Front. Public Health 2021, 9, 592795. [CrossRef]

93. Abid, R.; Ammar, A.; Maaloul, R.; Souissi, N.; Hammouda, O. Effect of COVID-19-Related Home Confinement on Sleep Quality, Screen Time and Physical Activity in Tunisian Boys and Girls: A Survey. Int. J. Environ. Res. Public Health 2021, $18,3065$. [CrossRef] [PubMed]

94. Elliott, S.; Drummond, M.J.; Prichard, I.; Eime, R.; Drummond, C.; Mason, R. Understanding the impact of COVID-19 on youth sport in Australia and consequences for future participation and retention. BMC Public Health 2021, 21, 1-16. [CrossRef] [PubMed]

95. Masi, A.; Diaz, A.M.; Tully, L.; Azim, S.I.; Woolfenden, S.; Efron, D.; Eapen, V. Impact of the COVID-19 pandemic on the well-being of children with neurodevelopmental disabilities and their parents. J. Paediatr. Child Health 2021, 57, 631-636. [CrossRef]

96. Munasinghe, S.; Sperandei, S.; Freebairn, L.; Conroy, E.; Jani, H.; Marjanovic, S.; Page, A. The Impact of Physical Distancing Policies During the COVID-19 Pandemic on Health and Well-Being Among Australian Adolescents. J. Adolesc. Health 2020, 67, 653-661. [CrossRef] [PubMed]

97. Reece, L.; Owen, K.; Foley, B.; Rose, C.; Bellew, B.; Bauman, A. Understanding the impact of COVID-19 on children's physical activity levels in NSW, Australia. Health Promot. J. Aust. 2020, 32, 365-366. [CrossRef] [PubMed]

98. Guan, H.; Okely, A.D.; Aguilar-Farias, N.; Cruz, B.D.P.; Draper, C.E.; Hamdouchi, A.E.; Florindo, A.A.; Jáuregui, A.; Katzmarzyk, P.T.; Kontsevaya, A.; et al. Promoting healthy movement behaviours among children during the COVID-19 pandemic. Lancet Child Adolesc. Health 2020, 4, 416-418. [CrossRef]

99. López-Gil, J.; Tremblay, M.; Brazo-Sayavera, J. Changes in Healthy Behaviors and Meeting 24-h Movement Guidelines in Spanish and Brazilian Preschoolers, Children and Adolescents during the COVID-19 Lockdown. Children 2021, 8, 83. [CrossRef] 